\title{
Pengembangan bahan ajar ipa dengan pendekatan inquiry untuk memfasilitasi siswa kelas VIII SMP/MTs dalam memahami konsep sistem pernapasan pada manusia
}

\author{
Nisa Nur Zakiyah, Susriyati Mahanal*, Erni Yulianti \\ Universitas Negeri Malang, Jl. Semarang No. 5 Malang, Jawa Timur, Indonesia \\ *Penulis korespondensi, Surel: susriyati.mahanal.fmipa@um.ac.id
}

Paper received: 01-04-2021; revised: 15-04-2021; accepted: 30-04-2021

\begin{abstract}
Abstrak
Tujuan penelitian ini adalah untuk mengembangkan bahan ajar IPA dengan pendekatan Iquiry untuk memfasilitasi siswa kelas VIII SMP/MTs dalam memahami konsep sistem pernapasan pada manusia serta menguji kelayakan dan kevalidan dari bahan ajar dalam bentuk buku siswa an buku guru. Pengembangan ini mengadaptasi model penelitian dan penembangan 4-D oleh Thiagarajan. Hasil penelitian menunjukkan kriteria bahawa bahan ajar yang dikembangkan tersebut layak dan valid. Berdasarkan hasil analisis diperoleh hasil persentase kevalidan dari ahli materi 98,65 persen, ahli media buku siswa 98,85 persen dan buku guru 100 persen serta praktisi lapangan 84,09 persen. Peningkatan hasil belajar memiliki perbedaan yang signifikan antara kelas eksperimen dan kelas kontrol. Rata-rata nilai sebesar 0,73 dengan kriteria efektivitas tinggi pada kelas eksperimen dan 0,37 dengan kriteria sedang pada kelas kontrol.
\end{abstract}

Kata kunci: Pengembangan bahan ajar; Iquiry; konsep sistem pernapasan

\section{Pendahuluan}

Mata pelajaran IPA pada kurikulum 2013 berorientasi pada pendekatan ilmiah yang mengarahkan peserta didik aktif atau memperoleh pengalaman secara langsung dalam kegiatan pembelajaran (Kemendiknas, 2013). Proses pembelajaran IPA berdasarkan kurikulum 2013 merupakan proses pembelajaran yang integratif atau terpadu. Pembelajaran yang terpadu bertujuan untuk meningkatkan efisiensi dan efektivitas pembelajaran sehingga dapat mencapai kompetensi dasar (Wisudawati, 2013). Prinsip pembelajaran IPA SMP/MTs seharusnya menghasilkan penilaian proses dan pemahaman konsep yang dapat meningkatkan keefektivitasan ketercapaian kompetensi lulusan (Hasanah, 2013). Namun pada proses pembelajaran IPA selama ini masih belum menyentuh kebermaknaan konsep pada pembelajaran di sekolah (Wisudawati, 2013)

Pemahaman konsep merupakan salah satu aspek yang perlu mendapatkan perhatian di dalam pembelajaran karena akan berujung pada hasil belajar siswa. Hasil belajar siswa diorientasikan sebagai refleksi untuk mengetahui penguasaan siswa terhadap suatu materi (Ayu, 2013). Menurut Sardiman, (2010) pemahaman (Understanding) atau pemahaman konsep dapat diartikan sebagai penguasaan sesuatu dengan pikiran. Pelaksanaan pemahaman konsep dilakukan apabila siswa dapat terlibat langsung dalam proses pembelajaran. Dengan siswa terlibat aktif dalam proses pembelajaran, siswa dapat lebih memahami konsep yang dipelajari. Pendekatan yang menuntut siswa untuk terlibat aktif dalam proses pembelajaran salah satunya adalah pendekatan inkuiri (Astuti, 2013).

Inkuiri merupakan sarana yang baik untuk membantu pemahaman atau proses berfikir siswa (Llewellyn, 2013). Pembelajaran inkuiri merupakan suatu pembelajaran yang menekankan pada penemuan yang diharapkan siswa dapat memecahkan masalah kritis dan mencari solusi dengan kreatif (Purwanti, 2016). Inkuiri dapat membantu mengembangkan 
kemampuan berpikir kritis, berpendapat dan berpikir selama proses penyelidikan ilmiah (Llewellyn, 2013). Strategi pembelajaran inkuiri terbimbing sangat efektif dan berpotensi untuk menyelesaikan permasalahan sehingga dapat diterapkan pada anak SMP (Ali, 2011). Sehingga sangatlah cocok apabila pembelajaran yang dilakukan difasilitasi dengan pendekatan inkuiri dengan model inkuiri terbimbing.

Shinta, (2013) menjelaskan bahwa Inkuiri terbimbing terbukti mampu melatihkan berpikir kritis dan keterampilan proses dalam sains. Tahapan dari inkuiri terbimbing yaitu guru berperan memberikan suatu permasalahan kepada siswa kemudian siswa mencari solusinya sendiri (Llewellyn, 2013). Pembelajaran dengan metode inkuiri terbimbing dapat meningkatkan pemahaman konsep dan kemampuan berpikir kritis siswa level sekolah tinggi, sedang dan rendah (Karim, 2011). Penilaian proses merupakan salah satu prinsip dari pembelajaran IPA. Prinsip pembelajaran IPA SMP/MTs seharusnya dapat meningkatkan keefektivitasan ketercapaian kompetensi lulusan. Tujuan tersebut dapat dicapai dengan diperlukannya rujukan yang baik dan benar bagi guru maupun peserta didik dalam bentuk bahan ajar (Hasanah, 2013).

Bahan ajar merupakan bagian yang sangat penting dari suatu proses pembelajaran secara keseluruhan (Ramdani, 2012). Bahan ajar yang digunakan haruslah mampu mencakup aspek pengetahuan, keterampilan, dan sikap yang harus dipelajari siswa untuk mencapai standar kompetensi yang telah ditentukan (Kemendiknas, 2006). Bahan ajar merupakan alat atau sarana untuk mencapai Standar Kompetensi (SK) dan Kompetensi Dasar (KD). Salah satu jenis bahan ajar yang digunakan sebagai sumber belajar adalah buku (Sutrisno, 2013). Buku ajar dapat membantu memfasilitasi siswa untuk mengembangkan pemahamannya tentang pengetahuan melalui konten atau konsep materi yang lebih kontekstual (Mahanani, 2015). Namun pada faktanya di lapangan buku ajar yang digunakan masih belum mampu membantu pemahaman konsep pada siswa dilihat dari hasil penelitian rendahnya hasil belajar ditunjukkan dengan nilai rata-rata nilai belajar kurang dari 75. Sesuai dengan hasil penelitian (Rahayu, 2011) dan (Kulsum, 2011) Apabila nilai hasil belajar siswa kurang dari 75 atau dibawah KKM maka dikatakan bahwa hasil belajar siswa pada sekolah SMP masuk dalam kategori rendah.

Menurut wawancara guru SMP Negeri di Kabupaten Malang serta penyebaran angket analisis kebutuhan guru pada bahan ajar, hasil persentase sebesar 70\% mengatakan bahwa bahan ajar yang digunakan cukup memadahi. Namun pada bahan ajar yang digunakan masih belum terurai materi yang diajarkan seperti pada kurikulum 2013 yang telah ditetapkan oleh pemerintah. Beberapa guru membutuhkan bahan ajar yang sesuai dengan kurikulum yang telah ditetapkan tersebut yaitu harus terpadu. Bahan ajar yang selama ini tersedia masih kurang membantu siswa dalam pemahaman konsep dan beberapa guru mengatakan bahwa siswa dapat lebih paham apabila materi yang diajarkan bisa dipelajari secara langsung atau menggunakan metode penemuan. Guru IPA yang ada biasanya memiliki kemampuan dasar fisika atau biologi saja sehingga kesulitan dalam menerpadukan mata pelajaran IPA. Beberapa guru mengatakan bahwa materi yang cukup sulit dalam pemahaman konsep adalah pada materi kelas VIII. Materi tersebut salah satunya adalah materi tentang sistem pernapasan pada manusia.

Berdasarkan permasalahan tersebut maka, perlu dikembangkannya suatu bahan ajar IPA yang mampu mengembangkan pemahaman konsep pada siswa pada materi yang ada 
pada kehidupan sehari-hari. Oleh karena itu, peneliti melakukan penelitian pengembangan dengan judul "Pengembangan Bahan Ajar IPA dengan Pendekatan Inquiry untuk Memfasilitasi Siswa Kelas VIII SMP/MTs dalam Memahami Konsep Sistem Pernafasan pada Manusia".

\section{Metode}

Penelitian ini menghasilkan produk berupa bahan ajar IPA berpendekatan Inquiry pada materi sistem pernapasan pada manusia. Model penelitian yang digunakan pada pengembangan ini mengadaptasi model 4-D Thiagarajan. Menurutu Thiagarajan, dkk (1974) model 4-D memiliki empat langkah diantaranya define, design, develop dan dessiminate. Model yang digunakan pada pengembangan ini terbatas hanya pada develope namun di uji dengan uji efektifitas bahan ajar pada proses pembelajaran.

Validator pada bidang ahli media dan ahli bahan ajar adalah seorang dosen pendidikan ipa dan guru IPA smp. Sedangkan untuk uji keterbacaan dan uji efektifitas bahan ajar dilakukan pada siswa smp kelas 8 pada SMPN 1 Srengat.

Data yang diperoleh dalam penelitian adalah data kualitatif dan kuantitatif. Data kualitatif diperoleh dari saran atau tanggapan yang diberikan validator ahli media, validator ahli materi dan praktisi lapangan.

\section{Tabel 3.2 Kriteria Penilaian Skala Likert}

\begin{tabular}{|l|l|}
\hline Peringkat & Kriteria \\
\hline 4 & $\begin{array}{l}\text { Sangat tepat/Sangat sesuai/Sangat menarik/Sangat } \\
\text { jelas/Sangat setuju }\end{array}$ \\
\hline 3 & Tepat/Sesuai/Menarik/Jelas/Setuju \\
\hline 2 & $\begin{array}{l}\text { Kurang tepat/ Kurang sesuai/Kurang menarik/Kurang } \\
\text { jelas/Kurang setuju }\end{array}$ \\
\hline 1 & $\begin{array}{l}\text { Tidak tepat/Tidak sesuai/ Tidak menarik/Tidak jelas/Tidak } \\
\text { setuju }\end{array}$ \\
\hline
\end{tabular}

(Diadaptasi dari Sugiyono, 2010)

Tabel 3.3 Kriteria Persentase Indikator Bahan Ajar

\begin{tabular}{lll}
\hline Kriteria kevalidan & Persentase & Keterangan \\
\hline Sangat valid & $100 \%$ & Tidak revisi \\
Valid & $75 \% \leq x \leq 100 \%$ & Tidak revisi \\
Cukup valid & $50 \% \leq x \leq 75 \%$ & Sedikit revisi \\
Kurang valid & $25 \% \leq x \leq 50 \%$ & Banyak revisi \\
Tidak valid & $0 \% \leq x \leq 25 \%$ & Revisi total \\
\hline
\end{tabular}

(Sumber: Arikunto, 2013)

\section{Hasil dan Pembahasan}

Produk pengembangan yang dihasilkan berupa bahan ajar IPA Terpadu dengan pendekatan Inquiry pada materi Sistem Pernapasan pada Manusia yang terdiri dari buku siswa dan buku guru. Pengembangan bahan ajar disesuaikan dengan model pengembangan yang digunakan yaitu model 4D namun terbatas pada tahap develop (define, design dan develop). Pada tahap develop dilakukan uji validitas yang berguna untuk menguji validitas atau kelayakan produk yang dikembangkan. Setelah itu dilakukan uji coba lapangan, tahapan ini berguna untuk mengetahui hasil belajar siswa yang menggunakan produk bahan ajar apakah membantu meningkatkan hasil belajar siswa atau tidak. 


\subsection{Data Hasil Validasi}

\section{Hasil Data Kuantitatif}

Tahap validasi ini dilakukan oleh ahli pendidikan yang terdiri dari dosen IPA UM dan guru IPA SMP Assalam Batu. Buku siswa dan buku guru diuji tingkat validitas (aspek materi dan media) berdasarkan angket validasi bahan ajar oleh dosen dan guru. Buku siswa juga diuji keterbacaan oleh siswa SMP kelas VIII. Sehingga diperoleh data kuantitatif dari angket validasi dan hasil uji keterbacaan yang disajikan pada Tabel 4.1 hingga Tabel 4.5 di bawah ini.

Tabel 4.1 Ringkasan Data Hasil Validasi Bahan Ajar oleh Ahli Materi

\begin{tabular}{llll}
\hline No & Aspek yang dinilai & Rata-rata \% & Kriteria \\
\hline 1 & Kebenaran materi & 100 & Sangat Valid \\
2 & Kedalaman materi & 95,8 & Valid \\
3 & Kesesuian materi dengan kurikulum & 100 & Sangat Valid \\
4 & Kesesuaian materi dengan pendekatan & 98,8 & Valid \\
& Inquiry & & \\
\hline Rata-ata nilai & $\mathbf{9 8 , 6 5}$ & Valid \\
\hline
\end{tabular}

Berdasarakan hasil perhitungan yang telah tercantum pada Tabel 4.1 diperoleh rata-rata hasil penilaian oleh ahli materi yaitu 98,65 \%. Nilai tersebut menunjukkan bahwa produk hasil pengembangan termasuk dalam kriteria valid.

Tabel 4.2 Ringkasan Data Hasil Validasi Bahan Ajar Buku Siswa oleh Ahli Media

\begin{tabular}{llll}
\hline No & Aspek yang dinilai & Rata-rata $\%$ & Kriteria \\
\hline 1 & Teknik penyajian & 100 & Sangat valid \\
2 & Komponen buku & 97,7 & Valid \\
\hline Rata-rata nilai & 98,85 & Valid \\
\hline
\end{tabular}

Tabel 4.3 Ringkasan Data Hasil Validasi Bahan Ajar Buku Guru oleh Ahli Media

\begin{tabular}{llll}
\hline No & Aspek yang dinilai & Rata-rata \% & Kriteria \\
\hline 1 & Teknik penyajian & 100 & Sangat valid \\
2 & Komponen buku & 100 & Sangat valid \\
\hline Rata-rata nilai & 100 & Sangat valid \\
\hline
\end{tabular}

Berdasarkan hasil perhitungan yang telah tercantum pada Tabel 4.2 dan Tabel 4.3 diperoleh hasil nilai rata-rata penilaian oleh ahli media yaitu untuk buku siswa memperoleh hasil penilaian 98,85 \% dengan kriteria valid dan buku guru memperoleh hasil penilaian $100 \%$ dengan kriteria sangat valid.

Tabel 4.4 Ringkasan Data Hasil Validasi Bahan Ajar oleh Praktisi Lapangan

\begin{tabular}{llll}
\hline No & Aspek yang dinilai & Rata-rata \% & Kriteria \\
\hline 1. & Keterbacaan bahan ajar & 84,09 & Valid \\
\hline Rata-rata Nilai & $\mathbf{8 4 , 0 9}$ & Valid \\
\hline
\end{tabular}


Berdasarkan analisis hasil perhitungan yang telah tercantum pada Tabel 4.4 diperoleh penilaian oleh praktisi lapangan yaitu 84,0 \% nilai tersebut menunjukkan bahwa produk pengembangan materi sistem pernapasan pada manusia termasuk dalam kriteria valid.

Tabel 4.5 Ringkasan Data Hasil Keterbacaan Bahan Ajar oleh Siswa

\begin{tabular}{llll}
\hline No & Aspek yang dinilai & Rata-rata \% & Kriteria \\
\hline 1 & Kemenarikan cover dan seluruh isi buku & 92,5 & Valid \\
2 & Identitas buku & 87,5 & Valid \\
3 & Desain tampilan bahan ajar & 95 & Valid \\
4 & Kejelasan kalimat & 95 & Valid \\
5 & Kalimat dan bahasa yang digunakan & 92,5 & Valid \\
6 & Urutan isi sesuai & 92,5 & Valid \\
7 & Jenis huruf & 95 & Valid \\
8 & Bahasa yang digunakan & 92,5 & Valid \\
9 & Tampilan gambar & 97,5 & Valid \\
10 & Pemahaman materi pada bahan ajar & 97,5 & Valid \\
\hline Rata-rata nilai & $\mathbf{9 3 , 7 5}$ & Valid \\
\hline
\end{tabular}

Berdasarkan hasil analisis keterbacaan siswa pada Tabel 4.5 diperoleh rata-rata nilai sebesar 93,75 \% dengan kriteria keterbacaan kriteria valid. Sehingga bahan ajar pengembangan dapat dikatakan sudah baik untuk digunakan.

Penelitian ini dilakukan uji Efektivitas bahan ajar untuk mengetahui bahan ajar yang dikembangkan apakah membantu siswa dalam memahami konsep sistem pernapasan pada manusia. Pemahaman konsep tersebut dilihat pada potensi peningkatan hasil belajar siswa. Untuk mengetahui potensi peningkatan tersebut dilakukan penelitian hasil belajar dengan menganalisis nilai pretest dan posttest siswa yang menggunakan bahan ajar pengembangan. Untuk mengetahui lebih dalam penelitian dilakukan dengan membandingkan dua kelas penelitian. Kelas yang pertama merupakan kelas yang menggunakan bahan ajar pengembangan pada proses pembelajaran dan kelas yang kedua adalah kelas yang menggunakan buku yang selama ini digunakan di sekolah. Dari hasil penelitian tersebut diperoleh data sebagai berikut.

Tabel 4.6 Hasil Uji Efektivitas Peningkatan Hasil Belajar Siswa pada Nilai Pretest dan Posttest

\begin{tabular}{lllll}
\hline Kelas & $\begin{array}{l}\text { Rata-rata } \\
\text { pretest }\end{array}$ & $\begin{array}{l}\text { Rata- } \\
\text { rata } \\
\text { posttest }\end{array}$ & $\begin{array}{l}\text { Hasil } \\
\text { peningkatan } \\
\text { (n-gain) }\end{array}$ & Kriteria \\
\hline Eksperimen & 50,36 & 86,67 & 0,73 & Efektivitas tinggi \\
Kontrol & 49,82 & 68,73 & 0,37 & Efektivitas sedang \\
\hline
\end{tabular}

Berdasarkan Tabel 4.6 diperoleh peningkatan hasil belajar dapat dilihat dari hasil nilai pada kelas uji coba yaitu kelas eksperimen dan kelas kontrol yang memperoleh hasil peningkatan nilai sebesar 0,73 dengan kriteria efektifitas tinggi pada kelas kontrol memperoleh hasil peningkatan nilai sebesar 0,37 dengan kriteria 
efektifitas sedang. Hal ini menujukkan bahwa bahan ajar hasil pengembangan memiliki efektifitas yang lebih tinggi.

Penilaian selanjutnya data kualitatif yang diperoleh dari hasil komentar, kritik dan saran dari validator ahli. Untuk mengetahui hasil data kualitatif yang diperoleh dapat dilihat pada Tabel 4.7 disajikan komentar, kritik dan saran dari para validator.

Tabel 4.7 Komentar dan Saran Validator

\begin{tabular}{lll}
\hline No & Validator & Komentar dan saran \\
\hline 1 & $\begin{array}{l}\text { Ahli } \\
\text { materi }\end{array}$ & $\begin{array}{l}\text { Pada materi gangguan pada sistem pernapasan pada } \\
\text { manusia karena tidak ada praktikum / percobaan maka } \\
\text { diperlukan media yang bisa digunakan sebagai pengganti } \\
\text { percobaan. }\end{array}$ \\
& Ahli Media & $\begin{array}{l}\text { Cover untuk buku guru dan siswa dibuat beda (misalkan } \\
\text { waranya) dibuat lebih menarik }\end{array}$ \\
3 & Ahli & $\begin{array}{l}\text { Buku guru halaman 1 perlu diedit beberapa kata yang } \\
\text { masih salah }\end{array}$ \\
& $\begin{array}{l}\text { Praktisi } \\
\text { Lapangan } \\
\text { (guru) }\end{array}$ & $\begin{array}{l}\text { Buku siswa halaman 29-31 bisa ditambahakan data } \\
\text { wawancara siswa dengan berkunjung ke puskesmas akan } \\
\text { lebih terlihat konseptualnya. }\end{array}$ \\
\hline
\end{tabular}

Setelah dilakukan penilaian secara kualitatif selanjutnya telah dilakukan revisi atau perbaikan sesuai dengan saran dan komentar yang diberikan oleh validator.

\section{Simpulan}

Berdasarkan penelitian pengembangan bahan ajar IPA dengan pendekatan inquiry untuk memfasilitasi siswa kelas VIII SMP/MTs dalam memahami konsep sistem pernapasan pada manusia, dihasilkan bahan ajar pengembangan yang layak dan valid untuk digunakan dalam proses pembelajaran. Kelayakan media dilihat pada penilaian ahli materi dan ahli media serta uji keterbacaan yang memperoleh hasil layak dan valid. Keefektivan dan kevalidan bahan ajar terlihat pada hasil rata-rata pretest dan posttest siswa yang dihitung menggunakan rumus $\mathrm{n}$ gain dengan membandingkan kelas eksperimen dan kelas kontrol. Didapatkan hasil $n$ gain memiliki efektivitas yang lebih tinggi dengan nilai 0,73 pada kelas yang menggunakan bahan ajar pengembangan. Sehingga Bahan Ajar IPA berpendekatan Inquiry untuk Memfasilitasi Siswa Kelas VIII SMP/MTs dalam Memahami Konsep Sistem Pernafasan pada Manusia layak digunakan untuk pembelajaran.

\section{Daftar Rujukan}

Aini, R. A. N. (2010). Pengaruh penggunaan bahan ajar IPA terpadu terhadap motivasi dan hasil belajar siswa kelas VII SMP Negeri I Wonosalam Kabupaten Jombang untuk materi pencemaran air (Doctoral dissertation, Universitas Negeri Malang).

Ali, T. G. P. (2011). Implementasi Pembelajaran Inkuiri dan Umpan Balik Terhadap Jurnal Belajar untuk Meningkatkan Kemampuan Unjuk Kerja dan prestasi Belajar IPA pada Siswa Kelas VII B SMP Negeri 5 Probolinggo. Malang: PPS Universitas Negeri Malang.

Amri, S., \& Ahmadi, I. K. (2010). Konstruksi pengembangan pembelajaran. Jakarta: Prestasi Pustaka.

Astuti, Y., \& Setiawan, B. (2013). Pengembangan lembar kerja siswa (LKS) berbasis pendekatan inkuiri terbimbing dalam pembelajaran kooperatif pada materi kalor. Jurnal Pendidikan IPA Indonesia, 2(1).

Creswell, J. W. (2012). Research design Pendekatan Kulaitatif, kuantitatif dan Mixed; Cetakan ke-2.

Damayanti, D. S., Ngazizah, N., \& Kurniawan, E. S. (2013). Pengembangan lembar kerja siswa (lks) dengan pendekatan inkuiri terbimbing untuk mengoptimalkan kemampuan berpikir kritis peserta didik pada 
materi listrik dinamis sma negeri 3 purworejo kelas x tahun pelajaran 2012/2013. RADIASI: Jurnal Berkala Pendidikan Fisika, 3(1), 58-62.

DI SMK PIRI, S. L. E. M. A. N., \& SUTRISNO, H. (2013). Pengembangan modul perhitungan konstruksi mesin.

Gilbert, S. W. (1991). Model Building and Definition of Science. Journal of research in science teaching, 28(1), 73-79.

Hake, R. R. (1999). Analyzing change/gain scores. Unpublished.[online] URL: http://www. physics. indiana. edu/ sdi/AnalyzingChange-Gain. pdf.

Hasanah, U., Dewi, N. R., \& Parmin, P. (2013). Pengembangan Bahan Ajar IPA Terpadu Berbasis Salingtemas Pada Tema Energi. Unnes Science Education Journal, 2(2).

Herry, A. H. dkk. 2015. Jurnal Pengembangan Bahan Ajar.

Karim, A. (2011). Penerapan metode penemuan terbimbing dalam pembelajaran matematika untuk meningkatkan pemahaman konsep dan kemampuan berpikir kritis siswa sekolah dasar. In Seminar Nasional Matematika dan Terapan (Vol. 30).

Kulsum, U., \& Hindarto, N. (2011). Penerapan model learning cycle pada sub pokok bahasan kalor untuk meningkatkan keaktifan dan hasil belajar siswa kelas VII SMP. Jurnal Pendidikan Fisika Indonesia, 7(2).

Llewellyn, D. (2013). Teaching high school science through inquiry and argumentation. Corwin Press.

Lubis, H. (2016). Upaya Peningkatan Hasil Belajar Siswa Pada Pelajaran IPS Materi Pokok Negara Maju Dan Negara Berkembang Melalui Penerapan Model Pembelajaran Inkuiri Di Kelas Ix-a SMP Negeri 39 Medan. Jurnal Penelitian Pendidikan Sosial Humaniora, 1(2), 80-86.

Mahanani, I. (2020). Pengembangan bahan ajar materi reaksi redoks dan elektrokimia menggunakan pendekatan saintifik dengan mengeksplisitkan hakikat sains (NOS) dan berpikir kritis. SKRIPSI Mahasiswa UM.

Meltzer, D. E. (2002). The relationship between mathematics preparation and conceptual learning gains in physics: A possible "hidden variable" in diagnostic pretest scores. American journal of physics, 70(12), 1259-1268.

Mustofa, L. R. (2013). Penerapan pendekatan inkuiri untuk meningkatkan hasil belajar siswa pada mata pelajaran ipa pokok bahasan daur air di kelas V semester 2 SDN Pancasila Kecamatan Lembang Kabupaten Bandung Barat (Doctoral dissertation, Universitas Pendidikan Indonesia).

Nasional, D. P. (2006). Permendiknas No. 22 Tahun 2006 tentang standar isi. Jakarta: Depdiknas.

Permendikbud, L. (2016). Peraturan Menteri Pendidikan dan Kebudayaan Republik Indonesia Nomor 20 Tahun 2016 Tentang Standar Kompetensi Lulusan Pendidikan Dasar dan Menengah. Jakarta: Menteri Pendidikan Nasional.

Purwanti Widhy, H. (2016) Inquiry Science Issues to Cultivate the Critical Thinking in Science Learning.

Rahayu, E., Susanto, H., \& Yulianti, D. (2011). Pembelajaran sains dengan pendekatan keterampilan proses untuk meningkatkan hasil belajar dan kemampuan berpikir kreatif siswa. Jurnal Pendidikan Fisika Indonesia, 7(2).

Ramdani, Y. (2012). Pengembangan instrumen dan bahan ajar untuk meningkatkan kemampuan komunikasi, penalaran, dan koneksi matematis dalam konsep integral. Jurnal Penelitian Pendidikan, 13(1), 44-52.

Sardiman, A. M. (2020). Interaksi \& motivasi belajar mengajar.

Setyosari, P. (2015). Metode Penelitian Pendidikan dan Pengembangan Cet. IV: Jakarta: Prenadamedia Group.

Sastrika, I. A. K., Sadia, W., \& Muderawan, I. W. (2013). Pengaruh model pembelajaran berbasis proyek terhadap pemahaman konsep kimia dan keterampilan berpikir kritis. Jurnal Pendidikan dan Pembelajaran IPA Indonesia, 3(2). 
Smp, P. D. D. S. M. P. Arikunto, S.(2013). Prosedur Penelitian, suatu pendekatan praktik. Jakarta: Rineka Cipta. Sugiyono.(2014). Statistika Untuk Penelitian. Bandung: Alfabeta. Sugiyono.(2011). Metode Penelitian Kombinasi (Mixed Methods). Bandung: Alfabeta. Jurnal Ppkn. Unj Online, 1(2), 2337-5205.

Siepmann, J. P. (1999). What is Science?. Journal of Theoretics, 1(3), 1-4.

Suastra, I. W. (2009). Pembelajaran sains terkini. Singaraja: Universitas Pendidikan Ganesha.

Sugiyono, S. (2010). Metode penelitian kuantitatif dan kualitatif dan R\&D.

Sugiyono, P. D. (2015). Metode Penelitian Pendidikan Sugiyono 2015 BAGIAN 3. Penerbit AlphaBeta.

Thiagarajan, S., Semmel, D. S., \& Semmel, M. I. (1974). Instructional development for training teachers of exceptional children.

Terpadu, T. I. (2009). Panduan Pengembangan Model Pembelajaran IPA TERPADU. Jakarta: Depdiknas.

Widodo, C. S., \& Jasmadi, S. T. P. (2008). Panduan menyusun bahan ajar berbasis kompetensi. Jakarta: Elex Media Komputindo.

Widoyoko, E. P. (2012). Teknik penyusunan instrumen penelitian. Yogyakarta: Pustaka Pelajar, 15, 22.

Wisudawati, A. W. (2013). Sulistyowati.(2014). Metodologi Pembelajaran IPA.

Zaman, B., \& Eliyawati, C. (2010). Bahan Ajar Pendidikan Profesi Guru (PPG) Media Pembelajaran Anak Usia Dini. Bandung: Pendidikan Guru Pendidikan Anak Usia Dini, Fakultas Ilmu Pendidikan, Universitas Pendidikan Indonesia. 